\title{
Egg quality characteristics of pullet chickens fed Neem (AzdirachtaIndica) leaf meal (NLM) managed under two housing systems
}

\author{
Kargbo, K. $.^{*}, \mathrm{Kanu}, \mathrm{S}^{2}$. \\ ${ }^{1}$ Sierra Leone Agricultural Research Institute, Teko Livestock Centre, Makeni. \\ ${ }^{2}$ Milton Margai College of Education Science and Technology, Sierra Leone
}

\begin{abstract}
A study was carried out with 180 dominant black strain pullet birds to evaluate the effect of neem and housing types on egg quality characteristics of pullets at point of lay. The birds were randomly assigned to two housing types (deep litter with run and deep litter housing) of 6 treatment groups comprising of 30 birds and 3 replicates of 10 birds each. The experiment was arranged in a $2 \times 3$ factorial layout in a completely randomized design. Diets containing neem leaf meal $(N L M)$ at $0,0.5$ and $1.0 \%$ was administered to birds. Data were collected egg external and internal characteristic at point of lay. Highest egg weight (45.53 g) was obtained in birds fed 0.5\% NLM. Bright yellow yolks were obtained from birds managed on deep litter housing with run. It was concluded that up to $1.0 \%$ NLM could be included in the diets of laying pullets to trigger early egg production and improve egg yolk colour.
\end{abstract}

Keywords_Egg, Housing, Neem, Pullets, Quality.

\section{INTRODUCTION}

The utilization of several medicinal plant as feed ingredient to reduce production cost in poultry diet is not new but the inclusion levels at various ages and physiological conditions varies [10,5]. Among these leaf is neem. Neem leaves is believed to have relieved so many different pains, fevers, infections and other complaints that it has been called the "village pharmacy[9] reported that eggs are good source of low cost high quality protein, providing 6.3grams of protein (13\% of the daily value of protein) in one egg for a caloric cost of only 68 calories. The structure of humans and animal is built on protein. We rely on animal and vegetable protein for our supply of amino acids and then our bodies rearrange the nitrogen to create the pattern of amino acids we require. According to [8] lutein a carotenoid thought to help prevent age related muscular degeneration and cataracts may be found in even higher amounts in eggs than green vegetables such as spinach, which have been considered its major dietary sources as well as supplements. However, the use of Neem leaf meal is limited due to bioactive compounds (Azadirachtin, limonoids and tannin) that have deleterious effects on nutrient utilization of monogastric animals $[6$, 2].

The present study was therefore undertaken to investigate the effects of varying levels of dried neem (Azadirachtaindica) leaf meal (NLM) in layers diets on the egg quality characteristics of pullets at point of lay.

\section{MATERIALS AND METHOD}

2.1 Location of the Experiment

The experiment was carried out at the Poultry unit of the Directorate of University Farms (DUFARMS), Federal University of Agriculture, Abeokuta, Ogun State. It fell within the rain forest vegetation zone of South-Western Nigeria at an altitude of $127 \mathrm{~m}$, latitude $7^{\circ} 13^{\prime} \mathrm{N}$ and longitude $3^{\circ} 26^{\prime} \mathrm{E}$. The climate is humid with a mean annual rain fall of $1037 \mathrm{~mm}$. The annual mean temperature is $34.7^{\circ} \mathrm{C}$ and relative humidity is $82 \%$. [4].

\subsection{Experimental diets}

The fresh green neem leaves were harvested from mature Neem trees within the environs of the university farms. The leaves were cleaned, made free of stems and sundried on a polyethylene sheet until they became crispy. They were milled and stored in sealed polyethylene bags until they were ready for diet formulation. Three experimental diets were formulated with neem leaf meal inclusion at $0,0.5$, and $1.0 \%$ to partially replace wheat offal and was offered to the birds from start to the end of the experiment. The ingredient compositions of the experimental diets are shown in Tables1

Table.1: Gross composition (\%) of grower's diets

\begin{tabular}{lccl}
\hline & \multicolumn{3}{c}{ \% Inclusion levels of neem leaf meal (NLM) } \\
Ingredients & 0 & 0.5 & 1.0 \\
\hline Maize & 50.00 & 50.00 & 50.00 \\
Soybean meal & 12.00 & 12.00 & 12.00 \\
Wheat offal & 33.00 & 32.5 & 32.0 \\
Azadirachtaindica & 0 & 0.5 & 1.0
\end{tabular}




$\begin{array}{llll}\text { Bone meal } & 2.00 & 2.00 & 2.00\end{array}$

$\begin{array}{llll}\text { Oyster shell } & 2.00 & 2.00 & 2.00 \\ \text { Lysine } & 0.25 & 0.25 & 0.25 \\ \text { Methionine } & 0.25 & 0.25 & 0.25 \\ \text { Grower's vit./trace } & 0.25 & 0.25 & 0.25 \\ \text { mineral premix } & & & \\ \text { Common Salt } & 0.25 & 0.25 & 0.25 \\ \text { Total } & 100.00 & 100.00 & 100.00\end{array}$

\section{Determined}

analysis (\%)

Crude protein

Ether Extract

$\begin{array}{lll}16.49 & 15.03 & 14.88 \\ 3.11 & 2.96 & 2.92 \\ 4.10 & 3.50 & 3.02 \\ 2.55 & 2.06 & 2.03 \\ 0.06 & 0.06 & 0.06 \\ 0.28 & 0.28 & 0.28 \\ 0.77 & 0.77 & 0.77 \\ 0.25 & 0.25 & 0.25 \\ 5.52 & 5.52 & 5.52\end{array}$

Crude fibre

Ash

Calcium

Phosphorus

Lysine

Methionine

Energy $(\mathrm{MJ} / \mathrm{Kg})$

2.00

0.25

.25

.25

00.00
Vit./Min. Premix contained: Premix (Embavit No 90) contained Vit. A, 10000 000iu; $\mathrm{D}_{3}, 2000$ 000iu; E, 12 $500 \mathrm{iu} ; \mathrm{K}, 1.30 \mathrm{~g} ; \mathrm{B}_{1}, 1.30 ; \mathrm{B}_{2}, 4.00 \mathrm{~g} ; \mathrm{D}$ CalciumPantothenate, $1.30 \mathrm{~g} ; \mathrm{B}_{6}, 1.30 \mathrm{~g} ; \mathrm{B}_{12}, 0.01 \mathrm{~g}$; nicotinic acid, $15.00 \mathrm{~g}$; folic acid, $0.05 \mathrm{~g}$; biotin, $0.02 \mathrm{~g}$; $\mathrm{Co}, 0.20 \mathrm{~g} ; \mathrm{Cu}$, $5.00 \mathrm{~g} ; \mathrm{Fe}, 25.00 \mathrm{~g}$; I, 0.06g; Mn, 48.00g; Se, $0.10 \mathrm{~g}$; Zn, 45.00g; choline chloride, 200.00g; BHT, 50.00g.

\subsection{Experimental birds and management}

Two hundred and thirty four (234) four weeks dominant black strain pullet chickens were brooded for four weeks and allotted to two housing systems of six treatment groups, each comprising of thirty nine (39) randomly selected birds in three (3) replicates of thirteen (13) birds each. Birds in treatments 1,2 and 3 were managed on deep litter with run while those in treatments 4,5 and 6 were managed in exclusive deep litter housing. Birds in treatments 1 and 4 fed control diet were given antibiotics from start to the end of the experiment, while those on treatments 2 and 5 and 3 and 6 were offered diets with NLM inclusion at 0.5 and $1.0 \%$, respectively. Newcastle, Infectious Bursal diseases and coccidiosis vaccinations were carried out routinely via drinking water. Vitamin was given prior to vaccination and at the end of each vaccination programme. The experiment lasted for a period of seventeen weeks.

\subsection{Egg External Qualities}

Weight of each first egg average over the number of first egg per group was measured with a balance sensitivity of
$0.01 \mathrm{~g}$. The length and width of each egg were measured using vernier calipers. The width was measured as the distance between two ends of the egg at the widest cross sectional region using vernier calipers. The length was measured as the distance between the broad and narrow ends of the egg. The Egg Shape Index (ESI) was calculated as the percentage of the egg breadth/broad end (width) to the egg length. The thicknesses of individual air-dried shell were measured to the nearest $0.01 \mathrm{~mm}$ using micrometer screw gauge.Egg shells were air dried in crates for three (3) days and weight of the dried shell was measured using a sensitivity balance of $0.01 \mathrm{~g}$.

\subsubsection{Egg Internal Qualities}

The eggs were gently broken and the maximum albumen heights were measured with tripod micrometer.The Albumen weight was determined the difference between the egg weight and the sum of weight of yolk and dry egg shell.\% Albumen weight was calculated as the percentage of the albumen weight to the egg weight.Yolk weightwas measured in grams using Mettler top-loading weighing balance. \% Yolk weightwas calculated as the percentage of the yolk weight to the egg weight.Yolk colourwas determined using yolk colour fan after the egg was broken and the yolk placed in Petri dish. Haugh unit (HU) was calculated using the values obtained for the egg weight and albumen height.

\section{RESULTS}

Table 2 shows results of the main effects of housing systems and varying inclusion levels of NLM on egg quality characteristics of grower pullets. The results showed that housing systems had no significant $(\mathrm{P}>0.05)$ influence on all the egg parameters measured except yolk colour. Likewise, inclusion of the NLM had no significant $(P>0.05)$ effect on shell thickness, shell weight, \% shell weight, albumen height, $\%$ albumen weight, $\%$ yolk weight and haugh unit. Birds on diet containing 0.5\% NLM laid eggs with the highest $(\mathrm{P}<0.05)$ values of egg weight, length, width, albumen weight, $\%$ albumen weight, yolk weight and \% yolk weight, however, the values are similar to egg laid by the birds fed the control diet. The birds fed $1.0 \%$ NLM laid eggs that had highest $(\mathrm{P}<0.05)$ value of egg shape index. The values of Haugh unit ranged $(\mathrm{P}>0.05)$ from 92.87 (control) to $96.21(0.5 \%$ NLM). 
Table.2: Main effects of housing systems and NLM inclusion on egg quality characteristics of grower pullets

\begin{tabular}{|c|c|c|c|c|c|}
\hline \multirow[b]{2}{*}{ Parameters } & \multicolumn{2}{|c|}{ Housing systems } & \multicolumn{3}{|c|}{$\%$ NLM inclusion level } \\
\hline & $\begin{array}{l}\text { Deep litter } \\
\text { with run }\end{array}$ & Deep litter & 0 & 0.5 & 1.0 \\
\hline Age at first $\operatorname{Egg}($ days $)$ & $144.33 \pm 2.80$ & $142.00 \pm 10.5$ & $147.5 \pm 4.51^{\mathrm{a}}$ & $146.5 \pm 1.29^{\mathrm{a}}$ & $135.5 \pm 8.85^{\mathrm{b}}$ \\
\hline Weight at $1^{\text {st }}$ lay $(\mathrm{kg})$ & $1.18 \pm 0.10$ & $1.19 \pm 0.08$ & $1.27 \pm 0.10^{\mathrm{b}}$ & $1.56 \pm 0.03^{\mathrm{a}}$ & $1.13 \pm 0.05^{\mathrm{b}}$ \\
\hline Egg weight (g) & $39.32 \pm 7.90$ & $39.30 \pm 7.05$ & $40.88 \pm 5.20^{\mathrm{a}}$ & $45.53 \pm 4.12^{\mathrm{a}}$ & $31.53 \pm 2.71^{\mathrm{b}}$ \\
\hline Egg length $(\mathrm{mm})$ & $50.18 \pm 4.32$ & $49.82 \pm 3.60$ & $50.62 \pm 2.77^{\mathrm{a}}$ & $53.61 \pm 1.38^{\mathrm{a}}$ & $45.78 \pm 1.26^{\mathrm{b}}$ \\
\hline Egg width $(\mathrm{mm})$ & $37.26 \pm 2.52$ & $37.49 \pm 2.17$ & $38.02 \pm 1.83^{\mathrm{a}}$ & $39.09 \pm 1.36^{\mathrm{a}}$ & $35.01 \pm 1.16^{\mathrm{b}}$ \\
\hline Egg shape index (\%) & $74.38 \pm 2.82$ & $75.34 \pm 1.75$ & $75.14 \pm 0.89^{\mathrm{ab}}$ & $72.95 \pm 2.93^{\mathrm{b}}$ & $76.48 \pm 1.18^{\mathrm{a}}$ \\
\hline Shell thickness $(\mathrm{mm})$ & $0.47 \pm 0.61$ & $0.47 \pm 0.73$ & $0.49 \pm 0.05$ & $0.46 \pm 0.07$ & $0.46 \pm 0.08$ \\
\hline Shell weight (g) & $4.32 \pm 1.29$ & $4.02 \pm 0.80$ & $4.23 \pm 0.54$ & $4.40 \pm 0.73$ & $3.88 \pm 1.70$ \\
\hline$\%$ shell weight & $11.36 \pm 4.67$ & $10.20 \pm 0.57$ & $10.34 \pm 0.61$ & $9.63 \pm 1.00$ & $12.36 \pm 5.62$ \\
\hline Albumen height $(\mathrm{mm})$ & $8.63 \pm 1.01$ & $7.43 \pm 1.00$ & $7.73 \pm 0.86$ & $8.68 \pm 1.00$ & $7.69 \pm 1.51$ \\
\hline Albumen weight (g) & $26.18 \pm 5.60$ & $26.28 \pm 5.45$ & $7.73 \pm 0.86^{\mathrm{a}}$ & $8.68 \pm 1.00^{\mathrm{a}}$ & $7.69 \pm 1.51^{\mathrm{b}}$ \\
\hline$\%$ Albumen weight & $66.33 \pm 4.38$ & $66.69 \pm 2.42$ & $26.70 \pm 3.19$ & $31.38 \pm 4.02$ & $20.63 \pm 2.38$ \\
\hline Yolk weight (g) & $8.82 \pm 2.25$ & $9.00 \pm 1.28$ & $9.95 \pm 1.53^{\mathrm{a}}$ & $9.75 \pm 0.83^{\mathrm{a}}$ & $7.03 \pm 1.00^{\mathrm{b}}$ \\
\hline$\%$ yolk weight & $22.31 \pm 3.37$ & $23.11 \pm 2.38$ & $24.28 \pm 0.71$ & $21.62 \pm 3.36$ & $22.23 \pm 1.55$ \\
\hline Yolk colour & $5.17 \pm 1.17^{\mathrm{a}}$ & $3.17 \pm 1.17^{\mathrm{b}}$ & $5.00 \pm 1.63^{\mathrm{a}}$ & $4.25 \pm 1.71^{\mathrm{ab}}$ & $3.25 \pm 0.96^{\mathrm{b}}$ \\
\hline Haugh unit & $97.74 \pm 5.09$ & $91.92 \pm 4.15$ & $92.87 \pm 4.71$ & $96.21 \pm 4.49$ & $95.40 \pm 7.45$ \\
\hline
\end{tabular}

${ }^{\text {abc }}$ Mean in the same row with uncommon superscript differed significantly $(\mathrm{P}<0.05)$; NLM= Neem Leaf Meal

Table 3 shows the results for the interactive effect of housing systems and NLM inclusion levels on egg quality characteristics of grower pullets. The results revealed significant $(\mathrm{P}<0.05)$ differences for almost all egg parameters. The interaction for means weight of bird at lay, shell thickness, shell weight, 5 shell weight, \% albumen weight and \% yolk weight were not significant $(\mathrm{P}>0.05)$. Birds on the deep litter fed diet that contained
$1.0 \%$ NLM inclusion came on lay earlier (128 days) than other groups. Parameters such as egg weight, length and yolk weight were more pronounced $(\mathrm{P}<0.05)$ in birds fed with diet contained $0.5 \%$ NLM inclusion for the two housing systems. Results for yolk and \% yolk weights are comparatively similar for birds fed with the control diet and $0.5 \%$ NLM inclusion in deep litter housing with run.

Table.3: Interactive effects of housing systems and NLM inclusion on the egg quality characteristics of grower pullets

\begin{tabular}{lcccccc}
\hline Housing systems & \multicolumn{3}{c}{ Deep litter with run } & Deep litter \\
NLM inclusion (\%) & 0 & 0.5 & 1.0 & 0 & 0.5 & 1.0
\end{tabular}

Parameters

\begin{tabular}{|c|c|c|c|c|c|c|}
\hline Age at first egg (g) & $144.5 \pm 4.95^{\mathrm{ab}}$ & $145.5 \pm 0.71^{\mathrm{ab}}$ & $143.0 \pm 2.83^{\mathrm{b}}$ & $150.5 \pm 0.71^{\mathrm{a}}$ & $147.5 \pm 0.71^{\mathrm{ab}}$ & $\begin{array}{l}128.0 \pm 1.41 \\
\mathrm{c}\end{array}$ \\
\hline Weight at 1 st lay $((\mathrm{kg})$ & $1.29 \pm 0.23$ & $1.15 \pm 0.04$ & $1.11 \pm 0.03$ & $1.25 \pm 0.11$ & $1.17 \pm 0.02$ & $1.16 \pm 0.06$ \\
\hline Egg weight (g) & $41.95 \pm 8.27^{\mathrm{ab}}$ & $45.40 \pm 1.98^{\mathrm{a}}$ & $30.60 \pm 0.28^{\mathrm{b}}$ & $39.80 \pm 2.83^{\mathrm{ab}}$ & $45.65 \pm 6.86^{\mathrm{a}}$ & $\begin{array}{l}32.45 \pm 4.31 \\
\mathrm{~b}\end{array}$ \\
\hline Egg length (mm) & $50.86 \pm 4.57^{\mathrm{ab}}$ & $53.98 \pm 1.63^{\mathrm{a}}$ & $45.71 \pm 0.35^{\mathrm{b}}$ & $50.38 \pm 1.36^{\mathrm{ab}}$ & $53.24 \pm 1.60^{\mathrm{a}}$ & $\begin{array}{l}45.86 \pm 2.16 \\
b\end{array}$ \\
\hline Egg width (mm) & $38.40 \pm 2.82^{\mathrm{ab}}$ & $38.83 \pm 1.25^{\mathrm{ab}}$ & $34.56 \pm 0.19^{b}$ & $37.65 \pm 1.24^{\mathrm{ab}}$ & $39.36 \pm 1.92^{\mathrm{a}}$ & $35.47 \pm 1.78$ \\
\hline Egg shape index $(\%)$ & $75.55 \pm 1.24^{\mathrm{ab}}$ & $71.99 \pm 4.49^{b}$ & $75.60 \pm 1.00^{\mathrm{ab}}$ & $74.73 \pm 0.45^{\mathrm{ab}}$ & $73.91 \pm 1.39^{\mathrm{ab}}$ & $\begin{array}{l}77.36 \pm 0.25 \\
\text { a }\end{array}$ \\
\hline Shell thickness (mm) & $0.50 \pm 0.02$ & $0.42 \pm 0.80$ & $0.51 \pm 0.04$ & $0.49 \pm 0.08$ & $0.51 \pm 0.04$ & $0.40 \pm 0.07$ \\
\hline Shell weight (g) & $4.15 \pm 0.92$ & $4.20 \pm 0.85$ & $4.60 \pm 2.55$ & $4.30 \pm 0.14$ & $4.60 \pm 0.85$ & $3.15 \pm 0.35$ \\
\hline$\%$ shell weight & $9.86 \pm 0.25$ & $9.22 \pm 1.47$ & $14.99 \pm 8.18$ & $10.82 \pm 0.41$ & $10.05 \pm 0.35$ & $9.72 \pm 0.20$ \\
\hline
\end{tabular}




$\begin{array}{lllllll}\text { Albumen height }(\mathrm{mm}) & 7.52 \pm 0.33^{\mathrm{bc}} & 9.48 \pm 0.10^{\mathrm{a}} & 8.90 \pm 0.10^{\mathrm{ab}} & 7.93 \pm 1.39^{\mathrm{abc}} & 7.88 \pm 0.62^{\mathrm{abc}} & 6.48 \pm 0.06^{\mathrm{c}} \\ \text { Albumen weight }(\mathrm{g}) & 27.60 \pm 4.95^{\mathrm{ab}} & 31.35 \pm 2.47^{\mathrm{a}} & 19.60 \pm 2.26^{\mathrm{b}} & 25.80 \pm 1.70^{\mathrm{ab}} & 31.41 \pm 6.51^{\mathrm{a}} & \begin{array}{l}21.65 \pm 2.76 \\ \mathrm{ab}\end{array} \\ & & & & & & \\ \text { \% Albumen weight } & 65.91 \pm 1.20 & 69.00 \pm 2.44 & 64.09 \pm 7.99 & 64.84 \pm 0.34 & 68.49 \pm 3.96 & 66.74 \pm 0.37 \\ \text { Yolk weight (g) } & 10.20 \pm 2.40^{\mathrm{a}} & 9.85 \pm 1.34^{\mathrm{a}} & 6.40 \pm 0.00^{\mathrm{b}} & 9.70 \pm 0.10^{\mathrm{ab}} & 9.65 \pm 0.49^{\mathrm{ab}} & 7.65 \pm 1.20^{\mathrm{ab}} \\ \text { \% yolk weight } & 24.22 \pm 0.95 & 21.78 \pm 3.91 & 20.92 \pm 019 & 24.35 \pm 0.76 & 21.46 \pm 4.31 & 23.54 \pm 0.58 \\ \text { Yolk color } & 6.0 \pm 1.41^{\mathrm{a}} & 5.5 \pm 0.71^{\mathrm{abc}} & 4.0 \pm 0.00^{\mathrm{abc}} & 4.0 \pm 1.41^{\mathrm{abc}} & 3.0 \pm 1.41^{\mathrm{bc}} & 2.5 \pm 0.71^{\mathrm{c}} \\ \text { Haugh unit } & 91.70 \pm 0.90^{\mathrm{bc}} & 100.02 \pm 0.92^{\mathrm{ab}} & 101.49 \pm 4.06^{\mathrm{a}} & 94.05 \pm 7.75^{\mathrm{abc}} & 92.39 \pm 1.17^{\mathrm{abc}} & 89.32 \pm 1.33 \\ & & & & & & \end{array}$

${ }^{\mathrm{abc}}$ Mean in the same row with uncommon superscript differed significantly $(\mathrm{P}<0.05)$; NLM= Neem Leaf Meal

\section{DISCUSSION}

The weight difference of the birds at first lay observed in this study could be attributed to the inclusion levels of the test ingredient and age at which the birds came to lay. The age of the birds could be a major factor that influenced the size of eggs produced. The values for shell weight and thickness were in close range with those reported by [3] who obtained non-significance effect of varying inclusion levels of NLM across treatments. The possibility of yolk score becoming a factor to the different sizes of egg has been proven false. The housing systems and inclusion levels of the NLM were relevant to yolk colour, yolk weight and \% yolk weight. The size of the egg affects the proportion of the yolk and other contents inside the egg. The colour score of egg from the control diets indicates that there was improved yolk coloration due to its rich xanthophyll content. This contrasts the works reported by [7]. The range of values obtained for haugh unit in this study was higher than those reported by [1] who reported 83.63-87.02. The average value of Haugh unit obtained in this study conforms to the values reported for standard commercial egg production guides. [9] also reported that haugh unit score of 72 and above has been graded as the best quality. This implies that the Haugh unit obtained in this study is of good standard.

\section{CONCLUSIONS}

Inclusion of NLM at $1 \%$ induced early egg production and quality egg shape index. Improved albumen and yolk colour were obtained in birds fed $0.5 \%$ NLM. And Bright yellow yolk was obtained from birds managed in deep litter housing with run.

\section{RECOMMENDATION}

From the results it can be concluded that neem leaf meal be included up to $1 \%$ in the diets of pullet chickens to induce early egg production.

\section{ACKNOWLEDGEMENT}

The author wishes to acknowledge the West African Agricultural Productivity Pragromme (WAAPP) Sierra
Leone and the Serra Leone Agricultural Research Institute (SLARi) for their financial and moral contributions in making this project a success.

\section{REFERENCES}

[1] Adedeji, O. S. Farinu, G. O. Olayemi, T. B. Ameen, S. A. andBabatunde, G. M.'Performance and egg Quality parameters of laying hens fed different dietary inclusion levels ofBitter kola (Garcinia kola)'. Research Journal of Poultry Science, 2008, pp. 75-7.

[2] Akpan, M. J. Enihi, G. E. Obasi, O L. Solomon, I. P. and Udedibie, A .B I . 'Effects of dietary Neem(Azadirachtaindica) leaf extract on performance of laying hens'. In Proceedings of the $33^{\text {rd Annual }}$ Conference of Nigerian Society for Animal Production Held atOlabisiOnabanjoUniversity ofAyetoro, Ogun State, 2008, pp.396-398.

[3] Dey, B. Chowdhury, S. D. Bulbul, S. M. and Chowdhury, B. L. D.' 'Efficacy of neem leaf meal as a hypocholesterolemic dietary additive in laying pullets'. Bangladesh Journal of AnimalScience. 2011, pp.13-17.

[4] Google Earth, 'http//www.google.earth' 2015.

[5] Ncube, S. Hamudikuwanda, H. and Saidi, P. T. "Voluntary feed intake and growth ofbroilers on Acacia angustissima leaf meal based starter and finisher diets", Livestock Research for rural Development. Unpublished.

[6] Ogbuewu, I. P. 'Physiological responses of rabbits fed graded levels of neem (Azadirachtaindica) leaf meal'2008.. M.Sc. Thesis Federal University of technology Owerri, Nigeria.

[7] Olabode, A. D. andOkelola, O. E. ''Effect of Neem Leaf Meal (Azadirachtaindica) on the Internal Egg Quality and SerumBiochemical Indices of Laying Birds'. Global journal of Biology,Agriculture and Health science, 2014,, pp. 25-27.

[8] Olabode, A. D."The effect of supplemental neem (Azadirachtaindica) leaf meal on thePerformance of broiler birds"'2008. An M. Sc Thesis University of Nigeria Nsukka-Nigeria. 
[9] Oluyemi, J. A. and Roberts, F. A. "Poultry production in warm-wet climate"'.Spectrumbooks Limited. Ibadan, Nigeria, 2000, Pp 24-49.

[10] Onyimonyi, A .E.Adeyemi,O.and Okeke, G. C. "Performance and economic characteristicsof broilers fed varying dietary levels of neem leaf meal (Azadirachtaindica) '. InternationalJournal of Poultry Science,2009, 256-259. 